\title{
The Effect of Calcium on Zoospore Differentiation in Phytophthora cinnamomi
}

\author{
By HELEN R. IRVING AND BRUCE R. GRANT* \\ The Russell Grimwade School of Biochemistry, University of Melbourne, Parkville, \\ Victoria 3052, Australia
}

(Received 6 December 1983; revised 13 February 1984)

\begin{abstract}
The removal of divalent cations from suspensions of zoospores of Phytophthora cinnamomi decreased cell viability. When zoospores were exposed to combinations of cations, the degree of zoospore encystment was reduced to the mean level of that stimulated by the two cations acting separately. When $\mathrm{Ca}^{2+}$ was present in mM concentrations, any damaging effect of the second cation was reduced. In the absence of added $\mathrm{K}^{+}$and $\mathrm{Ca}^{2+}$, the ionophores valinomycin and A23187 induced zoospore encystment within minutes. The addition of $\mathrm{Ca}^{2+}$ to zoospores treated with A23187 induced germination of the cysts. Strontium at $25 \mathrm{~mm}$ was as effective as $\mathrm{Ca}^{2+}$ in stimulating germination. The calmodulin-inhibitory drugs trifluoperazine, imipramine hydrochloride and dibucaine reduced zoospore viability and, with the exception of dibucaine, were ineffective at inducing encystment.
\end{abstract}

\section{INTRODUCTION}

Zoospores are motile, ellipsoidal, flagellate cells, which act as the dispersive element during the vegetative life cycle of fungi belonging to both the Chytridales and the Oomycetales. The dispersive phase of this cycle is terminated when the zoospore undergoes the processes of cyst formation (encystment) and cyst germination to form a new mycelium. During encystment, the swimming zoospore loses motility and changes from an ellipsoidal to a spherical form. Encystment is accompanied by loss of flagella and fusion of peripheral vesicles with the plasma membrane before the cell wall is formed. After cell wall formation is completed, the cyst can germinate by the formation of a germ tube and proceed to the mycelial state (Lunney \& Bland, 1976).

Zoospores are very sensitive to changes in the ionic environment and particularly to alterations in cation concentrations. This has been demonstrated in the monoflagellate zoospores of Blastocladiella emersonii (Soll \& Sonneborn, 1972; Jen \& Haug, 1981), and in the biflagellate zoospores of Aphanomyces astaci (Svensson \& Unestam, 1975) and Phytophthora cinnamomi (Byrt et al., 1982). Monoflagellate and biflagellate zoospores respond to different cations; the reasons for these differences are not known. To date, studies on the effects of cations have been carried out by increasing the concentration of a single ion many fold above the level of the remaining ions. In this paper we report the effect of increasing concentrations of pairs of cations on P. cinnamomi zoospores.

\section{METHODS}

Organism and cultural techniques. The culture of $P$. cinnamomi used originated as an isolate made by Dr G. Weste from Isopogon ceratophyllum in the Brisbane Ranges, Victoria, Australia. It is lodged in the CMI Institute, Kew, UK, as IMI 252489. The methods used for production of zoospores and for their subsequent handling have been described previously (Byrt \& Grant, 1979; Byrt et al., 1982). The experiments were conducted in plastic tissue culture trays (Linbro, Conn., USA; Sterilin, Middlesex, UK; or Lux, Calif., USA) in volumes between 2 and $3 \mathrm{ml}$. The $\mathrm{pH}$ of the solutions was maintained at 6.0 using $1 \mathrm{~mm}$-Tris/succinate buffer and incubation was at $21 \pm 2{ }^{\circ} \mathrm{C}$. 
Assay of cell populations. After treatment, cells were fixed in $1 \%(\mathrm{v} / \mathrm{v})$ neutralized glutaraldehyde containing $100 \mathrm{~mm}$-sorbitol. Populations were examined using an Olympus inverted microscope or by a Zeiss Ultraphot II fitted with a phase contrast, water immersion $40 \times$ objective. All results are reported as percentages of various cell types in the population, obtained by counting between 100 and 200 cells per chamber. Each treatment was usually replicated four times. Cysts were distinguished by their spherical shape, refractile cell wall and uniform, solid texture. Germinating cells were scored as such when they had a germ tube extending for at least $3 \mu \mathrm{m}$. Viability refers to the capacity of cells to produce germ tubes in the presence of $5 \% \mathrm{~V}-8$ broth containing $4 \mathrm{~mm}-\mathrm{Ca}^{2+}$, added to the treatment in question after $20 \mathrm{~min}$, and allowed to remain for a further 120-180 min. Populations with low viability also showed a high percentage of cells that had lysed or were showing other obvious signs of damage. These included vesicular blebs extending from the cell wall, ruffled outlines, or incomplete cyst wall formation. When cells germinated without added nutrient, as in the $\mathrm{Ca}^{2+}$ or $\mathrm{Sr}^{2+}$ treatment, this was described as germination.

Cation activities and concentrations. In all experiments involving cations, the activity of each cation, rather than its concentration, was considered. When combinations of cations were examined, the concentrations were adjusted so that activity of each ion under examination was equivalent to the activity which would have been present if it had been the sole ion. When only a single ion species was present, we refer to the concentration rather than activity, to allow comparison with previous work. The Debye-Hückel theory of interionic interactions was used to calculate cation activities (Barrow, 1973).

Total $\mathrm{Ca}^{2+}$ concentrations were measured by titration with disodium EDTA (Vogel, 1953) and free $\mathrm{Ca}^{2+}$ by means of a $\mathrm{Ca}^{2+}$ ion electrode (Radiometer, Copenhagen). The electrode measurements showed that the concentration of free $\mathrm{Ca}^{2+}$ present in zoospore suspensions containing between 50 and $80 \mu \mathrm{M}$ total $\mathrm{Ca}^{2+}$ was between 2 and $20 \mu \mathrm{M}$. $\mathrm{A} \mathrm{K}^{+}$-sensitive electrode (Radiometer) was used to measure free $\mathrm{K}^{+}$concentrations under the same conditions.

Chemicals. The ionophores A23187 and valinomycin were obtained from Calbiochem and added in ethanolic solution. Addition of equivalent amounts of ethanol $(<0.5 \%, \mathrm{v} / \mathrm{v})$ showed that it had no detectable effect on the $P$. cinnamomi zoospore population, but higher concentrations increased cell lysis. All other reagents were of AR grade and were used without further purification.

\section{RESULTS}

\section{Effects of chelators}

Zoospores of $P$. cinnamomi, as prepared by our method (Byrt \& Grant, 1979) require the immersion of a washed mat of mycelium containing the mature sporangia in distilled water, into which the zoospores are eventually released. During this period ions diffuse from the mycelial mat into the water resulting in a dilute salt solution by the time the zoospores actually appear. The divalent cations were sequestered by addition of the chelators EDTA or EGTA, and zoospore motility was not affected at concentrations up to $1 \mathrm{mM}$. As the concentrations of chelator increased from 0.01 to $1 \mathrm{mM}$, viability was reduced from 80 to $35 \%$. In EDTA, the reduction in viability was paralleled by cell lysis, but in EGTA less lysis was seen even though the ligand was more inhibitory in the viability assay. Germination in the viability assay in the presence of EGTA at concentrations of $0.3 \mathrm{mM}$ and above was highly asynchronous.

\section{Cation combinations}

(a) Monovalent/monovalent. The effect of two combinations of monovalent cations on zoospore encystment and viability was examined. The combination of $\mathrm{Na}^{+} / \mathrm{K}^{+}$was selected, as only small percentages of the zoospore populations encysted and even smaller percentages were damaged by $\mathrm{Na}^{+}$alone, whereas with $\mathrm{K}^{+}$, populations were immobilized with measurable damage (Byrt et al., 1982). In the same study, it was shown that $\mathrm{Cs}^{+}$severely damaged the zoospores without stimulating encystment and hence the effect of a $\mathrm{Cs}^{+} / \mathrm{K}^{+}$combination was examined.

As the concentration of $\mathrm{Na}^{+}$rose, the percentage encystment caused by $\mathrm{K}^{+}$fell (Table 1). This was particularly evident at $5 \mathrm{mM}-\mathrm{K}^{+}$, where $30 \%$ fewer cells encysted when $30 \mathrm{~mm}-\mathrm{Na}^{+}$ was present. Though the amount of encystment was reduced at increased concentrations of $\mathrm{Na}^{+}$, the population viability was marginally increased. Caesium also decreased the amount of encystment in $30 \mathrm{~mm}-\mathrm{K}^{+}$(Table 1 ). However, the viability of the zoospore population in the presence of $\mathrm{Cs}^{+}$was reduced at all $\mathrm{K}^{+}$concentrations. 
Table 1. Effect of the monovalent cation combinations $\mathrm{K}^{+} / \mathrm{Na}^{+}$and $\mathrm{K}^{+} / \mathrm{Cs}^{+}$on zoospore encystment $(E)$ and viability $(V)$

Results are the mean percentages $\pm \mathrm{SD}$ of four replications of each treatment.

\begin{tabular}{|c|c|c|c|c|c|c|c|c|}
\hline \multirow[b]{2}{*}{ Cation } & \multirow[b]{2}{*}{$\begin{array}{l}\text { Activity } \\
\text { (mM) }\end{array}$} & \multirow[t]{2}{*}{$\begin{array}{c}\mathrm{K}^{+} \\
\text {activity (mM) }\end{array}$} & \multicolumn{2}{|c|}{0} & \multicolumn{2}{|c|}{$4 \cdot 4$} & \multicolumn{2}{|c|}{$24 \cdot 7$} \\
\hline & & & E & V & E & V & $\mathrm{E}$ & V \\
\hline $\mathrm{Na}^{+}$ & $\begin{array}{c}0 \\
4.4 \\
24.7\end{array}$ & & $\begin{array}{l}40 \pm 1 \\
47 \pm 8 \\
59+9\end{array}$ & $\begin{array}{l}89 \pm 5 \\
78 \pm 5 \\
64+7\end{array}$ & $\begin{array}{l}76 \pm 7 \\
68 \pm 5 \\
42+7\end{array}$ & $\begin{array}{l}42 \pm 4 \\
43 \pm 6 \\
56 \pm 3\end{array}$ & $\begin{array}{l}65 \pm 2 \\
64 \pm 3\end{array}$ & $\begin{array}{l}55 \pm 7 \\
60 \pm 3\end{array}$ \\
\hline $\mathrm{Cs}^{+}$ & $\begin{array}{c}24 \cdot 7 \\
0 \\
4.4\end{array}$ & & $\begin{array}{l}59 \pm 9 \\
39 \pm 2 \\
44 \pm 3\end{array}$ & $\begin{array}{l}64 \pm 7 \\
85 \pm 1 \\
57 \pm 4\end{array}$ & $\begin{array}{l}42 \pm 7 \\
67 \pm 6 \\
64 \pm 5\end{array}$ & $\begin{array}{l}56 \pm 3 \\
59 \pm 3 \\
54 \pm 2\end{array}$ & $\begin{array}{l}44 \pm 5 \\
64 \pm 3 \\
46 \pm 5\end{array}$ & $\begin{array}{l}61 \pm 8 \\
59 \pm 4 \\
48 \pm 7\end{array}$ \\
\hline
\end{tabular}

Table 2. Effect of the di/monovalent cation combinations of $\mathrm{Ca}^{2+} / \mathrm{Na}^{+}$and $\mathrm{Ca}^{2+} / \mathrm{K}^{+}$on zoospore encystment $(E)$ and viability $(V)$

Results are the mean percentages \pm SD of four replications of each treatment.

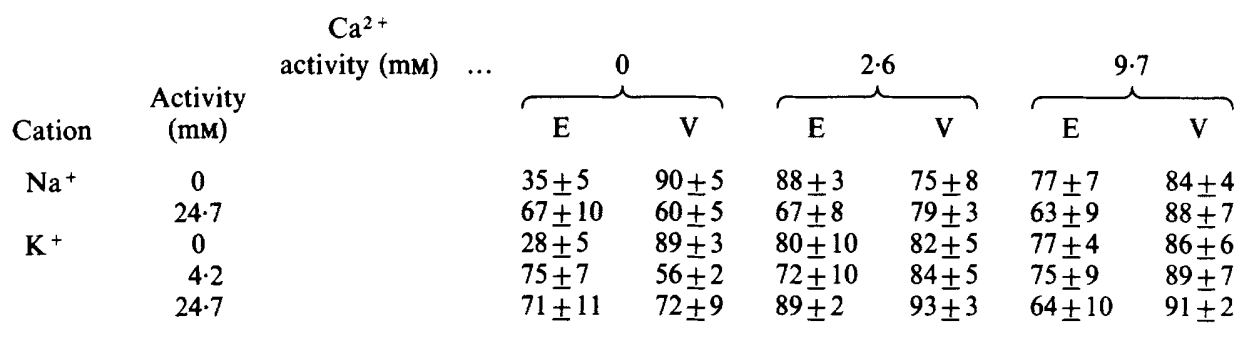

(b) Monovalent/divalent. The interactions of $\mathrm{K}^{+} / \mathrm{Ca}^{2+}$ and $\mathrm{Na}^{+} / \mathrm{Ca}^{2+}$ were examined. In both mono/divalent combinations, the presence of $\mathrm{Ca}^{2+}$ overrode any damage induced by the monovalent cation alone. In the $\mathrm{K}^{+} / \mathrm{Ca}^{2+}$ treatments, $50 \%$ of the zoospores were viable in $5 \mathrm{~mm}-\mathrm{K}^{+}$alone, but when $5 \mathrm{~mm}-\mathrm{Ca}^{2+}$ was added, the viability rose to $84 \%$ (Table 2). A similar situation was observed with the $\mathrm{Na}^{+} / \mathrm{Ca}^{2+}$ treatments. However, at $30 \mathrm{mM}-\mathrm{Na}^{+}$the presence of $\mathrm{Ca}^{2+}$ did not further increase the percentage of encystment recorded, though the viability of the cells increased.

At $\mu \mathrm{M}$ concentrations of $\mathrm{Ca}^{2+}$, as found in the normal release medium, $\mathrm{K}^{+}$-induced zoospore encystment and decreased cell viability, but at high $\mathrm{Ca}^{2+}$ levels the damaging effect of $\mathrm{K}^{+}$was alleviated. When the $\mathrm{Ca}^{2+}$ present in the zoospore suspension was reduced below $10^{-9} \mathrm{M}$ by the addition of EGTA, $10 \mathrm{mM}-\mathrm{K}^{+}$was much less effective in inducing zoospore encystment (Fig. 1). In $0.1 \mathrm{~mm}-\mathrm{Ca}^{2+}$, and in the presence of $10 \mathrm{~mm}-\mathrm{K}^{+}$, zoospores encysted rapidly, showing a time course similar to that reported previously for $\mathrm{K}^{+}$alone.

(c) Divalent/divalent. In a previous paper (Byrt et al., 1982) we stated that $\mathrm{Ca}^{2+}$ was the only cation which stimulated zoospores to encyst and germinate without the addition of nutrients. Subsequent work has shown that $\mathrm{Sr}^{2+}$ will mimic $\mathrm{Ca}^{2+}$ in this respect, as well as inducing encystment without reducing viability. When $\mathrm{Ca}^{2+}$ and $\mathrm{Sr}^{2+}$ were combined, no significant additive effect was observed either on the rate of zoospore encystment or upon the subsequent germination of cysts (Table 3).

(d) Divalent/trivalent. Although $\mathrm{La}^{3+}$ has been considered to substitute for $\mathrm{Ca}^{2+}$ in some classes of reaction (Takata et al., 1967) it was found to be highly toxic to P. cinnamomi zoospores when applied in low concentrations (Byrt et al., 1982). Combinations of $\mathrm{Ca}^{2+}$ and $\mathrm{La}^{3+}$ showed no interaction in the induction of zoospore encystment (Table 4). However, $10 \mathrm{~mm}-\mathrm{Ca}^{2+}$ overcame the toxicity induced by $1 \mu \mathrm{M}-\mathrm{La}^{3+}$ alone. The presence of $\mathrm{Ca}^{2+}$ also induced all viable $\mathrm{La}^{3+}$-treated cells to germinate without addition of nutrient.

In summary, the combinations of the various cations tested showed little synergistic effect on zoospore encystment. The effect of single cations on encystment appeared to be averaged when 


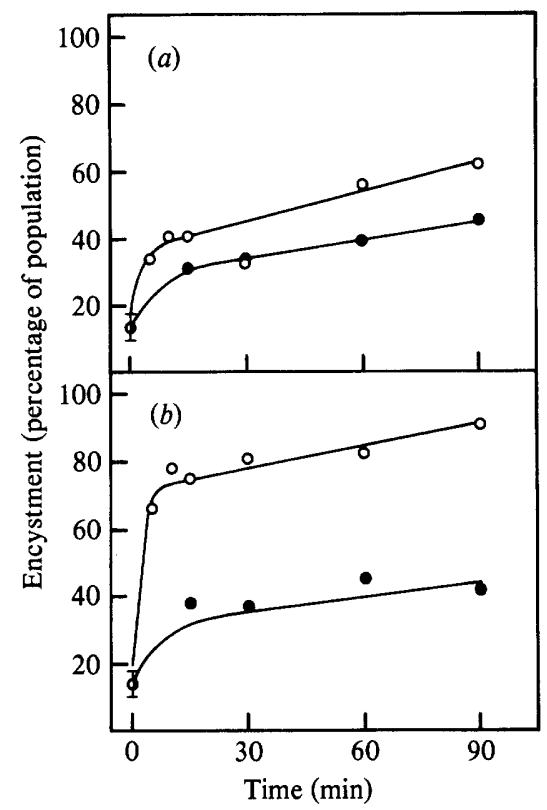

Fig. 1. Effect of the concentration of $\mathrm{Ca}^{2+}$ on encystment of zoospores. $\mathrm{Ca}^{2+}$ was measured with a $\mathrm{Ca}^{2+}$ electrode and the $\mathrm{Ca}^{2+}$ concentration was adjusted with either EGTA or $\mathrm{CaCl}_{2}$. Zoospores were left untreated $(O)$ or treated with $10 \mathrm{~mm}-\mathrm{K}^{+}(\mathrm{O})$. The cells were fixed and results are the mean of duplicate samples. (a) Zero $\mathrm{Ca}^{2+} ;\left(\right.$ b) $0 \cdot 1 \mathrm{mM}-\mathrm{Ca}^{2+}$.

Table 3. Effect of the divalent cation combination of $\mathrm{Ca}^{2+} / \mathrm{Sr}^{2+}$ on zoospore encystment $(E)$ and germination $(G)$

Results are the means \pm SD of four replicates. $\mathrm{Sr}^{2+}$

$$
\begin{gathered}
\mathrm{Ca}^{2+} \text { activity } \\
\text { (mM) }
\end{gathered}
$$

0

$4 \cdot 1$ activity (mM)

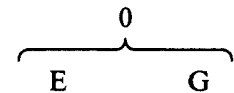

$\begin{array}{lr}37 \pm 5 & 8 \pm 4 \\ 57 \pm 6 & 25 \pm 8 \\ 62 \pm 10 & 49 \pm 3\end{array}$



$57 \pm 4 \quad 21 \pm 7$

$63 \pm 7 \quad 34 \pm 6$

$70 \pm 7 \quad 55 \pm 4$



$\begin{array}{ll}61 \pm 6 & 53 \pm 12 \\ 54 \pm 6 & 53 \pm 8 \\ 63 \pm 11 & 63 \pm 5\end{array}$

Table 4. Effect of the tri/divalent cation combination of $\mathrm{La}^{3+} / \mathrm{Ca}^{2+}$ on zoospore encystment $(E)$, viability $(V)$ and germination $(G)$

Results are the means \pm SD of four replicates.

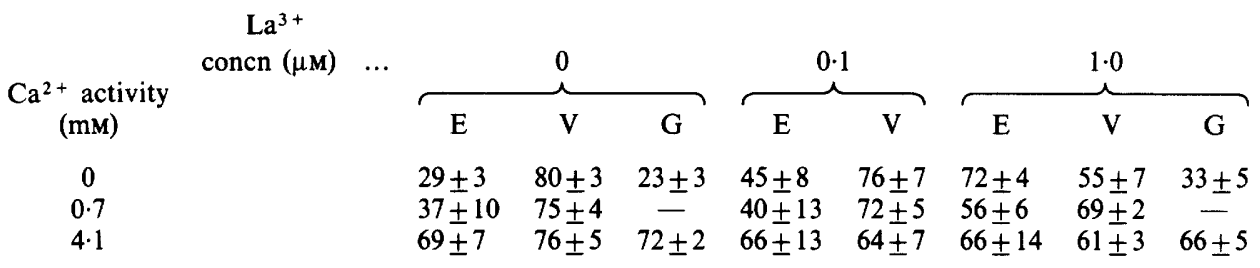

they were combined. However, the effect of $\mathrm{Ca}^{2+}$ was paramount and its presence reduced damage observed in the presence of high concentrations of other ions.

\section{Effect of ionophores}

The effect of a given ion on a zoospore may be the result of its action at the membrane surface or on internal functions. These possibilities can be distinguished in part by ionophores which catalyse the transfer of specific ions across membranes. The addition of the $\mathrm{K}^{+}$ionophore 


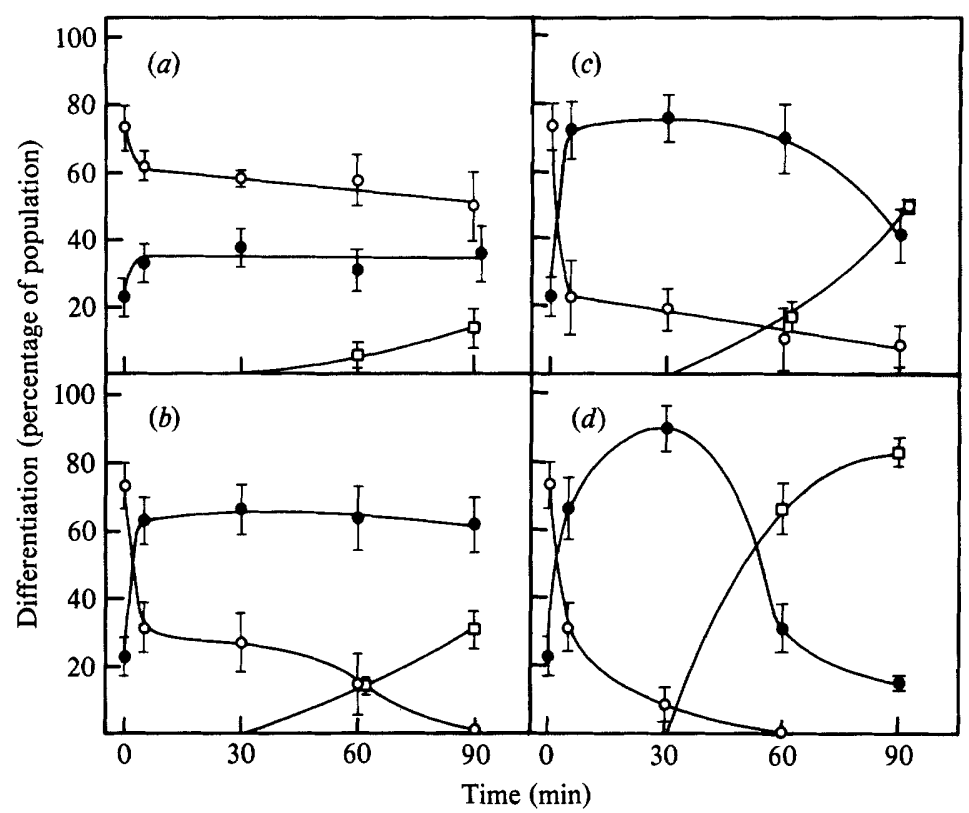

Fig. 2. Zoospore behaviour in the presence of various concentrations of $\mathrm{Ca}^{2+}$ and the ionophore A23187. Results are the mean \pm SD of four replicates of the cell types: zoospores $(O)$, cysts $(O)$ and germlings ( $\square$ ). (a) Control; (b) $1 \mu \mathrm{M}-\mathrm{A} 23187$; (c) $1 \mu \mathrm{M}-\mathrm{A} 23187$ and $1 \mathrm{mM}-\mathrm{Ca}^{2+}$; (d) $25 \mathrm{mM}-\mathrm{Ca}^{2+}$.

valinomycin to zoospore suspensions caused $60 \%$ encystment. Measurements with a $\mathrm{K}^{+}$ electrode showed that free $\mathrm{K}^{+}$in the suspension was between 50 and $70 \mu \mathrm{M}$. This concentration of $\mathrm{K}^{+}$, in the presence of valinomycin, produced the same degree of encystment as observed with $10 \mathrm{~mm}-\mathrm{K}^{+}$alone. No further encystment was obtained even when $\mathrm{K}^{+}$was increased to $1 \mathrm{mM}$ in the presence of valinomycin.

The $\mathrm{Ca}^{2+}$ ionophore A23187 also induced encystment in the zoospore population at much lower free $\mathrm{Ca}^{2+}$ concentrations than in its absence. When the external $\mathrm{Ca}^{2+}$ concentration was adjusted to $50 \mu \mathrm{M}$ by the addition of sufficient EGTA to complex $\mathrm{Ca}^{2+}$ in excess of this level, $1 \mu \mathrm{M}$-A23187 induced encystment in $70 \%$ of the population in $20 \mathrm{~min}$ but this was not increased further by the addition of $\mathrm{Ca}^{2+}$ up to $1 \mathrm{mM}$. At $50 \mu \mathrm{M}$ external $\mathrm{Ca}^{2+}$, the presence of $\mathrm{A} 23187$ reduced viability to $45 \%$, in contrast to $68 \%$ in the controls. Increasing the external $\mathrm{Ca}^{2+}$ level to $300 \mu \mathrm{M}$ in the presence of $1 \mu \mathrm{M}-\mathrm{A} 23187$ restored the viability to that of the control population. Although A23187 increased the rate of zoospore encystment observed in the presence of low external $\mathrm{Ca}^{2+}$ concentrations, it had much less effect on the rate of germination, which after $90 \mathrm{~min}$ incubation was only $11 \%$ above that of the control population (Fig. $2 a, b$ ). When the external $\mathrm{Ca}^{2+}$ was increased to $1 \mathrm{mM}$, in the presence of $1 \mu \mathrm{M}-\mathrm{A} 23187$ there was a marked increase in the germinating cysts and at $90 \mathrm{~min} 48 \%$ had germinated. However, $20 \mathrm{~mm}-\mathrm{Ca}^{2+}$ alone induced $78 \%$ of the population to germinate (Fig. $2 c, d$ ).

\section{Effect of anti-calmodulin drugs}

Calmodulin is a small Ca-binding protein which has been implicated in many reactions in which $\mathrm{Ca}^{2+}$ has been shown to play a regulatory role. Although not specifically demonstrated to be present in Phytophthora cells, it has been reported as being present in other fungi (OrtegaPerez et al., 1981) and appears to be ubiquitous in eukaryotes (Klee et al., 1980). Since $\mathrm{Ca}^{2+}$ clearly plays a role in $P$. cinnamomi zoospore differentiation, the effect of three drugs, each known to block $\mathrm{Ca}^{2+}$-calmodulin mediated reaction, was examined. Only one of the three, dibucaine $(10 \mu \mathrm{M})$, increased the percentage of encysted zoospores from 40 to $60 \%$. Both trifluoperazine, a phenothiazine derivative, and imipramine hydrochloride, a tricyclic anti- 
depressant, reduced motility at concentrations above $10 \mu \mathrm{M}$. Trifluoperazine at $30 \mu \mathrm{M}$ caused $100 \%$ immobilization, and only $10 \%$ of the cells remained viable. Imipramine also reduced viability, and at $100 \mu \mathrm{M}$ only $23 \%$ of the cells were viable. Dibucaine was less effective and at $100 \mu \mathrm{M}, 43 \%$ of the cells were viable.

\section{DISCUSSION}

Cations can influence zoospores in two distinct ways. By adsorption onto the zoospore plasma membrane they may either stabilize or destabilize the membrane. In the extreme case, destabilization leads to cell lysis while lesser levels of perturbation can effect conformational changes of the specific protein components of the membrane system. This in turn can result in a number of intracellular changes. Action of this type should be considered in terms of the GouyChapman theory of diffuse double layers (McLaughlin, 1977). The negatively charged zoospore membrane induces higher concentrations of ions near the zoospore-water interface than in the bulk of the water. If cations acted on zoospores in this way alone it would be expected that their activity would follow the Hofmeister ion series and there would be the possibility of substitution of one species by another to induce the same effect.

Changes in external ion concentration can also change the fluxes of ions across the plasma membrane and hence the intracellular ion balance. Alteration in intracellular ion levels can act as a trigger to induce a cascade of intracellular events. In this type of action, specific external ions would be required to induce the observed effect and the Hofmeister ion series would not predict whether an ionic species could act as an inducer. It has been demonstrated that the addition of specific ions to suspensions of zoospores does induce rapid depolarization of the membranes in Blastocladiella emersonii (Jen \& Haug, 1981), at the same time causing them to encyst and germinate (Soll \& Sonneborn, 1972). This clearly demonstrates transmembrane ion fluxes. We have recently shown that in $P$. palmivora a similar depolarization was induced when either $\mathrm{Ca}^{2+}$ or $\mathrm{Sr}^{2+}$ were added to the spore suspension $(\mathrm{H}$. R. Irving \& B. R. Grant, unpublished). These same ions trigger encystment in $P$. palmivora, as they do in $P$. cinnamomi, although in the latter species low zoospore concentrations limit investigation of the intracellular events by conventional techniques.

It has been stated that low concentrations of cations were necessary to maintain zoospore motility in Phytophthora (Cameron \& Carlile, 1980). Our results suggest that divalent cations at least are more important in the maintenance of viability rather than the motility of the zoospore phase. The zoospores of $P$. cinnamomi appear well adapted to survival in media with a total ionic strength at least as low as $0 \cdot 1 \mathrm{~mm}$. High concentrations of certain ions, for example $\mathrm{Mg}^{2+}, \mathrm{NH}_{4}^{+}$ and $\mathrm{La}^{3+}$, do appear to disrupt the cells (Byrt et al., 1982) and such effects could be the result of non-specific changes in the ionic double layer surrounding the cell (Rubin et al., 1981), which in this stage lacks any external cell wall. However, it is unlikely that these effects are responsible for the ion-induced differentiation in $P$. cinnamomi. The lack of syngergistic or additive effects in the paired ion treatments point to specific effects, particularly of $\mathrm{Ca}^{2+}$ ions. When $\mathrm{Ca}^{2+}$ was present at concentrations sufficient to induce differentiation, it did so regardless of the concentration of other ions such as $\mathrm{La}^{3+}$ or $\mathrm{K}^{+}$which would otherwise reduce viability or induce lysis. We interpret this effect in terms of the rapidity of $\mathrm{Ca}^{2+}$-induced encystment nullifying the slower, non-specific ion effects on the zoospore system.

Our results also point to the probability that at least part of the $\mathrm{K}^{+}$-induced encystment is mediated by $\mathrm{Ca}^{2+}$. Reducing $\mathrm{Ca}^{2+}$ below $1 \mathrm{nM}$ greatly diminishes the effect of $\mathrm{K}^{+}$on a zoospore population as the characteristic immobilization and rounding up of the cells is absent. The effect is restored when $\mathrm{Ca}^{2+}$ is supplied at $100 \mu \mathrm{M}$. At the concentrations involved, $100 \mu \mathrm{M}-\mathrm{Ca}^{2+}$ and $10 \mathrm{mM}-\mathrm{K}^{+}$, it is hard to explain these effects in terms of changes in membrane screening charges, effected by $\mathrm{Ca}^{2+}$ on $\mathrm{K}^{+}$ions.

Potassium can induce the formation of open $\mathrm{Ca}^{2+}$ channels in other systems, such as the secretory vesicles isolated from adrenal medullae (Kreiger-Brauer \& Gratzl, 1982). If this is the case in $P$. cinnamomi zoospores, it would provide an explanation for the effects observed, as $\mathrm{K}^{+}$ would be acting in a manner similar to $\mathrm{Ca}^{2+}$ ionophore. Since $\mathrm{Ca}^{2+}$ alone induced encystment 
and germination when supplied at $25 \mathrm{~mm}$ or above, it seems possible that at this concentration there is a sufficient leak of $\mathrm{Ca}^{2+}$ to initiate whatever processes are required to begin differentiation. $\mathrm{As} \mathrm{Sr}^{2+}$ can replace $\mathrm{Ca}^{2+}$ completely in this step and is effective over the same concentration range, this ion must be able to substitute freely for $\mathrm{Ca}^{2+}$ in whatever processes are involved. It has been reported that $\mathrm{Sr}^{2+}$ does substitute for $\mathrm{Ca}^{2+}$ in certain other systems in which $\mathrm{Ca}^{2+}$ serves as a stimulus to secretion (Best et al., 1981).

The addition of the $\mathrm{Ca}^{2+}$ ionophore $\mathrm{A} 23187$ results in $\mathrm{Ca}^{2+}$ stimulation of zoospore differentiation at concentrations two orders of magnitude below that observed in its absence. However, higher concentrations of $\mathrm{Ca}^{2+}$ were required to stimulate germination in the presence of A23187 than were needed to stimulate encystment. The $\mathrm{K}^{+}$ionophore valinomycin also allowed the induction of encystment at low external $\mathrm{K}^{+}$concentrations. The results are therefore consistent with the hypothesis that $\mathrm{Ca}^{2+}$ acts on $P$. cinnamomi zoospores by altering the internal $\mathrm{Ca}^{2+}$ balance rather than by acting directly on the plasma membrane. At least one ion, $\mathrm{K}^{+}$, appears to act by altering the permeability of the cells or a compartment within the cells to $\mathrm{Ca}^{2+}$.

However, the failure of the anti-calmodulin drugs to inhibit encystment or, at low concentrations, germination suggest that if changes of internal $\mathrm{Ca}^{2+}$ are important in initiating zoospore differentiation, $\mathrm{Ca}^{2+}$ does not directly involve a $\mathrm{Ca}$-calmodulin complex. The immobilization and inhibition of germination observed at high concentrations may be due to membrane stabilization, a side effect of these calmodulin-inhibitory drugs. This has also been observed in erythrocytes (Bereza et al., 1982).

There is an array of other proteins which depend upon $\mathrm{Ca}^{2+}$ for their activity but which are independent of calmodulin. These proteins are particularly important in the interaction with the cytoskeleton of the cell, and appear to be ubiquitous in eukaryotes (Geiger, 1983). One example is fragmin, which binds to actin and has the ability to sever filaments (Petrucci et al., 1983). Changes in cell shape and concomitant secretion of cellular vesicular contents are characteristic of the encystment of Phytophthora zoospores and in other cell types it has now been demonstrated that these changes are a direct consequence of the transient changes in intracellular $\mathrm{Ca}^{2+}$ levels. It therefore seems likely that this or a similar mechanism operates in the zoospore system.

This work was supported by grants from the Die-back Research Foundation, the Potter Foundation and the Buckland Foundation. H. R. I. was supported by a University of Melbourne Postgraduate Scholarship.

\section{REFERENCES}

Barrow, G. M. (1973). Physical Chemistry, 3rd edn. Tokyo: McGraw-Hill.

Bereza, U. L., Brewer, G. J. \& Mizukami, I. (1982). Association of calmodulin inhibition, erythrocyte membrane stabilization and pharmacological effects of drugs. Biochimica et biophysica acta 692, 305-314.

Best, L. C., Bone, E. A. \& Russell, R. G. G. (1981). Strontium ions stimulate phosphoinositide metabolism in human blood platelets. FEBS Letters 134, 88-90.

Byrt, P. N. \& Grant, B. R. (1979). Some conditions governing zoospore production in axenic cultures of Phytophthora cinnamomi Rands. Australian Journal of Botany 27, 103-115.

Byrt, P. N., IRVING, H. R. \& Grant, B. R. (1982). The effect of cations on zoospores of the fungus $P h y$ tophthora cinnamomi. Journal of General Microbiology 128, 1189-1198.

Cameron, J. N. \& Carlile, M. J. (1980). Negative chemotaxis of zoospores of the fungus Phytophthora palmivora. Journal of General Microbiology 120, 347353.
GeIGER, B. (1983). Membrane cytoskeletal interactions. Biochimica et biophysica acta 373, 305-341.

Jen, C. J. \& Haug, A. (1981). Potassium-induced depolarization of the transmembrane potential in Blastocladiella emersonii zoospores precedes encystment. Experimental Cell Research 131, 79-87.

KleE, P. B., Crouch, T. H. \& Richman, P. G. (1980). Calmodulin. Annual Review of Biochemistry 49, 489515.

Kreiger-Brauer, H. \& Gratzl, M. (1982). Uptake of $\mathrm{Ca}^{2+}$ by isolated secretory vesicles from adrenal medulla. Biochimica et biophysica acta 691, 6170.

LUNNEY, C. Z. \& BLAND, C. E. (1976). Ultrastructural observations of mature and encysting zoospores of Pythium proliferum de Bery. Protoplasma 90, 199237.

McLaughlin, S. (1977). Electrostatic potentials at membrane-solution interfaces. Current Topics in Membrane Transport 9, 71-143.

Ortega Perez, R., Van Tunien, D., Marme, D., Cox, J. A. \& TURIan, G. (1981). Purification and identi- 
fication of calmodulin from Neurospora crassa. FEBS Letters 133, 205-208.

Petrucci, T. C., Thomas, C. \& Bray, D. (1983). Isolation of a $\mathrm{Ca}^{2+}$-dependent actin fragmenting protein from brain, spinal cord and cultured neurones. Journal of Neurochemistry 40, 1507-1516.

Rubin, B. T., Chow, W. S., \& Barber, T. (1981). Experimental and theoretical considerations of mechanisms controlling cation effects of thylakoid membrane stacking and chlorophyll fluorescence. Biochimica et biophysica acta 634, 174-190.

Soll, D. R. \& SonNeborn, D. R. (1972). Zoospore germination in Blastocladiella emersonii. IV. Ion control of cell differentiation. Journal of Cell Science 10, 315-333.

Svensson, E. \& UNESTAM, T. (1975). Differential induction of zoospore encystment and germination in Aphanomyces astaci, Oomycetes. Physiologia Plantarum 35, 210-216.

Takata, M., Pickard, W. F., LetTirn, J. Y. \& MOORE, T. W. (1967). Ionic conductance changes in lobster axon membrane when lanthanum is substituted for calcium. Journal of General Physiology 50, 461-471.

VOGEL, A. I. (1953). Textbook of Quantitative Inorganic Analysis. London, UK: Longman. 